\title{
Individual and social influences on students' attitudes to debt: a cross-national path analysis using data from England and New Zealand
}

\author{
Neil Harrison, University of the West of England, \\ neil.harrison@uwe.ac.uk \\ Steve Agnew, University of Canterbury, \\ steve.agnew@canterbury.ac.nz
}

\begin{abstract}
This study examines the construction of debt attitudes among 439 first year undergraduates in England and New Zealand. It works from a theoretical model that predicts that attitudes will be partly determined by a range of social factors, mediated through personality and 'financial literacy'. Path analysis is used to explore this model. The proposed model was found to be basically sound, with some notable negative findings. Socio-economic status was found to have a negligible role in determining debt attitudes, while the role of financial literacy was limited to reducing the likelihood of seeing debt as useful for lifestyle expenditure. Debt anxiety was found to be higher among students with a general predisposition to anxiety and inversely related to viewing student debt as a form of educational investment. It is concluded that student debt attitudes are multidimensional and individualised, challenging simplistic ideas of debt aversion in earlier literature.
\end{abstract}

\section{Acknowledgements}

The lead author would like to acknowledge financial support (grant reference SG130227) from the Leverhulme Trust via the British Academy's Small Grants Programme. Both authors would also like to acknowledge the contribution of Joyce Serido; due to technical difficulties, the data she collected in the United States proved unusable for this study. 


\section{Introduction}

Indebtedness has increasingly become part of the student experience across the developed world, especially within English-speaking countries (Usher, 2005). However, relatively little is known about the attitudes that students hold about their situation or what factors work to construct these attitudes. This study uses a quantitative approach to data collected from first year undergraduates from England and New Zealand (NZ) soon after the start of their studies. It seeks to explore the impact of a range of social and individual variables on four dimensions of debt attitude, as well as contrasting the results between the two countries and two subject disciplines.

England and NZ are appropriate choices for this study in that they have student loan systems that have been constructed on broadly similar principles. Furthermore, these student loan systems are 'mature' in the sense that indebtedness has become an expected experience for the vast majority of students [1]. Both have components for tuition fees and for living costs and require repayment after graduation once an income threshold has been reached, through repayments calculated on income over this threshold:

- Student loans were introduced in NZ in 1992, in response to the introduction of tuition fees in 1989 and the ability of universities to set their own level of fees in 1991, which prompted large percentage increases in the fees students paid. Around 82 percent of NZ students now take loans with around NZ\$13,500 available per year; unusually, loan interest is pegged at zero in absolute terms. Repayments are 12 percent of income over a threshold of around NZ\$19,000. The median graduate salary one year after graduation is approximately NZ\$38,000, with 94 percent in work or further study (Ministry of Education, 2015a,b). 
- In England, student loans were phased in across the early 1990s, but increased markedly with increases in tuition fees in 2006 and 2012. Loan use among English students is now around 95 percent, with a maximum of around $£ 14,500$ per year available. Interest accrues on a means-tested scale up to 3 percent above inflation. Repayments are 9 percent of income over $£ 21,000$. The median graduate salary six months after graduation is approximately $£ 20,000$, with 90 percent in work or further study (Higher Education Statistics Agency, 2015).

The two countries therefore have similar labour markets in terms of the employment and earnings expectations of graduates. However, NZ has a lower total level of debt available which declines in real value over time, while England has less onerous repayment terms, with a higher threshold and lower repayment rate, but interest at or over inflation. In both instances, the income-contingent nature of the repayments makes the loans preferential in comparison to commercial forms of consumer credit, albeit that students may not view them as such.

England and NZ therefore provide comparators that might be typified as 'similar, but different', allowing an exploration of whether contrasting terms and conditions for student loans are associated with different debt attitudes, while limiting potentially confounding factors; the two nations also share significant elements of cultural heritage. Furthermore, they have been the location for much of the research to date on student debt attitudes.

\section{Literature review}

Student debt has come under increasing academic scrutiny with much of this literature focusing on the effects of indebtedness on individual students. For example, Cooke et al. (2004) and Jessop, 
Herberts and Solomon (2005) report that students with higher levels of debt and/or financial concern are more likely to experience mental health issues such as anxiety and depression. Watson, Barber and Dziurawiec (2014) argue that perceived pressures on students to economise lead to depression and lowered life satisfaction, while Shim et al. (2009) find that 'extreme' debt avoidance measures (e.g. working very long hours) also impact on physical health and academic success. A large-scale English survey (Department of Innovation, Universities and Skills, 2009) found that nearly three-quarters of students experienced financial worries at some point in their studies, while a recent report from the NZ Union of Students' Associations (2014) highlights students' concerns about the impact of debt across their lifecourse. Debt is often argued to be causal in part-time working during studies which limits available study time (e.g. Shim et al., 2009; Hall, 2010; Richardson et al., 2013). It has long been suggested that financial difficulties are linked to early withdrawal (Quinn et al., 2005; National Audit Office, 2007; Dwyer et al., 2013), although others have questioned whether financial constraints translate directly into academic difficulties and whether withdrawal is more driven by the ability to meet day-to-day expenses than indebtedness per se (Christie et al., 2004; Harding, 2011).

A fear of debt is often hypothesised to be a major determinant in the demand for higher education, especially among prospective students from lower socio-economic groups (e.g. Gorard et al., 2007; Wilkins et al., 2013; Leach, 2013). However, the data to support this assertion are mixed at best, potentially drawing more on a simplistic application of ideas of supply, demand and price than focused analysis. Applications and admissions data from England for the periods in which indebtedness has grown rapidly shows no decline from young students from lower income backgrounds and an initial drop from older students is now reversing (Higher Education Funding Council for England [HEFCE], 2013; Independent Commission on Fees [ICF], 2014; Grove, 2014). These data actually show a drop in demand from the most affluent groups who might be thought 
most able to avoid, or mitigate, indebtedness. McLaughlin (2003) makes a similar point in the NZ context, where demand rose rapidly alongside costs.

While Callender and Jackson (2005) assert that debt aversion is associated with lower demand from disadvantaged students, the effect they identify is small and the measure used of questionable validity. Bachan's (2013) more rigorous work finds no significant relationship between debt aversion and indebtedness, echoing Eckel et al.'s (2007) Canadian study. Maringe et al. (2009) do identify some debt aversion among prospective students, but conclude that it has little dissuasive power in light of the attractions of higher education, while the Office for Fair Access (2015) finds that financial incentives (that could mitigate indebtedness) are largely ineffective in influencing demand for students from low income backgrounds.

These latter studies suggest that either debt aversion is not substantially linked to socio-economic status or that it has a limited role in determining behaviour - or both. Davies et al.'s (2008) work suggests that prospective students have a nuanced approach to finance, while Purcell et al. (2008) conclude that finance is a minor component in prospective students' decision-making processes. Wilkins et al. (2013) report that finance is a major source of variation within prospective students attitudes to higher education, but - counterintuitively - it is more affluent individuals that are more likely to consider cheaper options. One reason for this may be a continued belief in a high graduate premium from a degree (Walker and Zhu, 2011; Davies et al., 2013) and that indebtedness is a 'necessary evil' to access higher level and more rewarding employment in the long-term (Esson and Ertl, in press). Students with higher salary expectations also expect to accumulate more debt (Bachan, 2013) and have lower anxiety about debt (Purcell and Elias, 2010).

Students from lower socio-economic groups are often found to have higher levels of debt (e.g. Harding, 2011; Bachan, 2013), with limited family support to fall back on, although no difference 
was found in the most recent large-scale English survey (Department for Business, Innovation and Skills [BIS], 2013). However, certain groups such as South Asians (in England) and Māori (in NZ) tend to be less indebted (Ministry of Education, 2005; BIS, 2013), potentially due to culturallyinfluenced attitudes. Furthermore, there is good evidence that some students seek to minimise their debt through strategies such as choosing universities so as to remain within the family home (Patiniotis and Holdsworth, 2005; BIS, 2013), especially those from minority ethnic communities who may have cultural reasons to stay within their community. As such, concerns about debt may not significantly undermine the overall demand for higher education, but it may influence some students' choices.

A significant body of research has concurred that women are more likely to be debt averse than men across a wide range of situations (see Kamleitner et al., 2012), including student debt (Bachan 2013), although this does not necessarily translate into lower overall debts (Pollard et al., 2013). Kettley et al. (2008) find that female students use a range of coping strategies to ameliorate their higher anxiety, compared to 'complacent men' who are more likely to get into financial difficulty (e.g. missing repayments). The reason for higher debt aversion among women is not yet wellunderstood, but it may be related to more generalised attitudes to risk (Croson and Gneezy, 2009) or to differing financial experiences in adolescence (Lusardi and Tufano, 2008; Organisation for Economic Cooperation and Development, 2014).

McManus and Furnham (2006) find that students with extrovert personality traits are more likely to prize social expenditure, while Metcalf (2005) and Harrison and Chudry (2011) argue that these students then accumulate higher debts to meet these costs. The latter also find that a general disposition towards anxiety was a strong predictor for specific anxiety about student debt, although it did not influence borrowing behaviour. Nicholson et al. (2005) argue for a strong relationship between personality and risk-taking attitudes and behaviours. 
Another individual factor that is widely held to influence attitudes and behaviour is knowledge about financial concepts, products and processes; often referred to as 'financial literacy'. Lusardi and Mitchell (2014) review the theory and research literature on financial literacy and its link to day-to-day financial management skills (Hilgert et al., 2003); individuals with high financial literacy are held to make more rational decisions in terms of borrowing. Lower financial literacy is correlated with more expensive borrowing including paying higher fees and using high-cost borrowing channels (Mottola 2013), notably in young adults (de Bassa Scheresberg 2013). Women and people from lower socio-economic groups are generally found to have lower financial literacy levels, as well as there being large inter-country differences (Lusardi and Mitchell, 2008; 2014). However, Marriott (2007) examined students' financial literacy, but found no differences by gender and no connection to debt aversion or levels of debt.

Davies and Lea's (1995) pioneering work in the field saw students' debt attitudes as existing on a single continuum between aversion and comfort, although more recent work has cast doubts on this unidimensionality (Norvilis et al., 2006; Eckel et al., 2007). For example, using NZ data, Haultain et al. (2010) argue that attitudes should be measured on two dimensions comprising 'fear of debt' and 'debt utility' (i.e. that debt is useful by increasing purchasing power). Chudry et al. (2011), using UK data, propose four dimensions, but find that only responsible attitudes to financial management predict behaviour. Peltier et al. (2013) find that debt aversion is associated with higher levels of debt rather than lower (also see Bachan, 2013), posing questions about causality, while students who reported being impulsive and valuing their social status were more likely to borrow.

\section{Conceptual model and research questions}


The literature reviewed above provides a conceptual grounding for this study. Debt attitudes are taken to be complex and multidimensional, with components reflecting anxiety, perceived utility and desire for engagement with financial processes. These are asserted to be predicted by a range of demographic factors including socio-economic status, gender and ethnicity, as well as individual components of personality. Finally, the individual's understanding of financial concepts and processes is taken to have a mediating role between the social/individual factors and debt attitudes. This conceptual model is shown graphically in Figure 1.

[Figure 1 here]

Based on this conceptual model, this study seeks to address the following research questions:

1. Do particular social groups (by gender, ethnicity, socio-economic status, nationality and degree subject) have significantly different attitudes to debt?

2. Are these attitudes mediated through commonly-used measures of personality?

3. What role does financial literacy have in predicting debt attitudes and what is its relationship to personality and social factors?

\section{Methodology}

This study is quantitative, using an online questionnaire to capture self-reported data which are subjected to statistical analysis. However, it is based within a pragmatic paradigm that respects the socially-constructed nature of reality as understood by the participants. Indeed, it draws on earlier qualitative work (Harrison et al., 2015) with a similar student cohort which provided a rich 
understanding of the diverse lived experiences of indebtedness among contemporary students. The purpose of this subsequent study was, therefore, to develop new understanding about how these experiences might be predicted by a range of individual and social factors. Such relationships are not taken to be deterministic, nor necessarily constant through time or between situations.

The study works from a multidisciplinary perspective, drawing on psychology, sociology and economics. It rejects reductionist ideas about rationality which have generally failed to predict student behaviour. Instead, it works from a critical form of 'behavioural economics' which sees attitudes and decisions as situated within the 'bounded rationality' (Simon, 2000) of the individual and mediated through their membership of social groups contribute shared understandings, beliefs and norms.

This study was conducted in two universities - one each in England and NZ. These were mid-status institutions recruiting across a wide social and academic profile, and broadly typical of their national context in terms of demographics. As such, they were felt to be defensibly representative of their nations, given the resource constraints of the study. The sampling frame comprised fulltime undergraduates in their first year in business (including management, marketing, accountancy, commerce, economics and applied mathematics) or social science (including sociology, psychology, politics and education). These disciplines were selected on the basis that they were well-represented in both universities by similar programmes, thereby reducing any confounding effect of different student/subject mixes. There was no age criterion within the sampling frame, but international students were excluded as their eligibility for student loans differs from home students. The ramifications of the selection of universities and disciplines is discussed further in the Limitations section below.

An original questionnaire was piloted in England and a number of refinements made as a result. 
The final questionnaire took the following form:

- Debt attitudes. A 20-item inventory was developed based on the findings in Harrison et al. (2015), using a five-point Likert scale. Fourteen items were subsequently used to construct four scales representing separate dimensions of debt attitudes as described in Harrison, Agnew and Serido (2015); see Appendix A. The anxiety scale (ANX: 4 items) measured how worried students felt about their level of indebtedness. The investment scale (INVEST: 4 items) measured the extent to which students felt that their debt would bring long-term benefits. The lifestyle scale (LIFE: 3 items) measured the propensity to use debt for social and luxury expenditure. The awareness (AWARE: 3 items) measured how informed students were in the practical arrangements surrounding their debt. All four scales were found to have a sufficiently strong Cronbach alpha $(\mathrm{ANX}=.817, \mathrm{INVEST}=.643, \mathrm{LIFE}=.760$ and AWARE=.721); the variable used was the mean on a five-point scale.

- Financial literacy. Students were asked to complete a five-item multiple choice test of their financial literacy, broadly following the principles set out by Lusardi and Mitchell (2007) and Mandell (2008), who have demonstrated that short tests of this nature provide a valid proxy for deeper financial understanding. The questions covered inflation, compound interest, commercial credit and sales tax. The test was positively marked and participants therefore received a score between zero and five (FLSCORE).

- Personality. The BFI-10 inventory (Rammstedt and John, 2007) was used to collect data on five personality scales commonly used within the literature on individual differences: extraversion (EXT), neuroticism (NEU), conscientiousness (CON), agreeableness and openness-to-experience. Each of these scales comprised two items on a five-point Likert scale and the variable used was the mean. The Cronbach alpha for the three first scales was 
found to be somewhat low, but acceptable, for two-item scales (EXTRA $=.574, \mathrm{NEU}=.568$ and $\mathrm{CON}=.513$ ), but those for agreeableness and openness-to-experience were not sufficiently internally reliable and were therefore omitted from the study.

- Social factors. Data were collected on gender, age group (under 21 vs. 21 and over), degree subject and nationality. Data were also collected on ethnicity (majority vs. minority group) and the level of qualifications attained by the participants' parents (degree vs. lower), but, for reasons explored shortly, these were not used in the final analysis.

The data were collected in the first half of the students' first year of study, between October 2013 and January 2014. There was a deliberate decision to focus on newly-registered students so as to capture data when the experience of indebtedness was novel, when individual debt levels were not excessively divergent and before a familiarity with indebtedness had a chance to influence attitudes (Davies and Lea, 1995; Purcell and Elias, 2010); it is acknowledged that data collected later in the student lifecycle may differ. No attempt was made to distinguish between student loan borrowing and other forms of credit (e.g. overdrafts or credit cards), on the basis that it was unlikely that students would have accrued significant amounts of the latter so early in their studies. The focus, therefore, is on an abstract notion of 'student debt' and the attitudes that surround it, rejecting a simplistic construction of 'debt aversion' found in some previous studies.

A similar approach to data collection was used in both universities. The questionnaire was rendered online using Moodle in NZ and SurveyMonkey in England, with e-mail and in-person reminders being provided over the course of one month; a near-identical version of the questionnaire was used, with minor differences to accommodate local vocabulary. Responses from students outside the sampling frame and those without debt were subsequently removed by hand. A prize draw incentive was used to increase response rates and ameliorate self-selection bias by engaging with 
individuals who might not typically respond to an unsolicited survey invitation.

\section{Descriptive statistics}

The sample comprised 439 students: 240 from NZ and 199 from England. The demographic composition of the sample is displayed in Table 1; the sample constitutes a response rate of 17 percent, which is relatively high for a general online survey. The sample was found to be broadly demographically representative of the populations from which it was drawn, although women were slightly over-represented and students from minority ethnic groups were slightly under-represented. On this basis, it was concluded that the self-selection of participants was not a significant source of bias in terms of the measured variables.

[Table 1 here]

Table 2 shows the descriptive statistics for the continuous variables. The mean score on the NEU scale was close to the midpoint, while the EXT and CON scales were somewhat above average in the context of a five-point scale. Anxiety about debt (ANX) was generally low within the sample, as was the perceived utility of debt for lifestyle purposes (LIFE). Conversely, mean scores on the INVEST and AWARE scales were above the midpoint.

[Table 2 here]

Analysis 
The dataset was analysed using path analysis within a structural equation model, with Amos v20 overlaying SPSS v20 (Blunch, 2013). Path analysis is an extension of multiple regression analysis, enabling significant relationships between variables to be identified while holding other variables constant, with the additional benefit of being able to handle potentially causal chains of variables.

An initial structural model was built from the conceptual model presented above. Checks confirmed that all the continuous variables were satisfactorily normal in distribution and the initial model was analysed using a maximum likelihood approach. This model was refined by adding new paths suggested by the modification indices - in this instance, to allow the personality variables and debt attitudes to themselves be interrelated. The model was then simplified by the removal of nonsignificant paths (at the 5 percent level) and the final model is presented as Figure 2 [2]. Fitness measures suggest that the model is a strong fit for the data $\left(\chi^{2}{ }_{31}=31.245, \mathrm{p}=.453, \mathrm{CFI}=1.000\right.$, $\mathrm{RMSEA}=.004, \mathrm{SRMR}=0.030)[3]$.

[Figure 2 here]

Most notably, this process of simplification effectively eliminated two variables from the analysis. Socio-economic status (as measured through parental education levels) was found to have no significant paths. Ethnicity was found to have some limited role within the model, but the specific ethnic subsamples were too small to analyse this further with confidence. Given the limited impact on the overall model, the decision was taken to remove ethnicity; this will require focused attention in future research.

[Tables 3 and 4 here] 
Estimated regression weights and their standard errors are shown in Table 3, with covariances in Table 4. For the demographic variables, the regression weights can be understood as the average additional score for the group in question relative to the reference group - for example, women, on average, scored .13 points lower on the INVEST scale than men, all else being equal. For the financial literacy test and personality scales, the regression weights represent the average additional score on the debt attitude variables for each additional point on the independent variable - for example, for every additional point on the EXT scale, the LIFE score was .27 points higher. The regression weights for the error terms (e1 to e8) were, following convention, set to 1 and the variances of the individual error terms are shown on Figure 2.

\section{Findings and discussion}

The path analysis reveals a complex picture of relationships. The debt attitudes explored all have distinct families of predictors and are themselves moderately interrelated, supporting a multidimensional framework in contrast to previous work suggesting that debt attitudes are unidimensional.

Awareness of the student finance system was the dimension most specifically driven by personality, being related to all three traits used in this study. Students with a strong knowledge about their own loans and their repayment terms were more likely to report being generally conscientious, introverted and emotionally stable. This latter finding is perhaps surprising, in that it might be assumed that those of an anxious disposition would be more likely to find out about the loans they are acquiring. However, this may fit into a wider pattern of denial which was identified in Harrison et al. (2015) as a belief that student debt was something to be ignored in the short-term and left for 'future self' to be concerned with; a similar phenomenon was also found among students with very 
active social lives. Less surprising was the finding that mature students had higher levels of awareness than their younger counterparts.

The belief in the usefulness of debt for maintaining a preferred lifestyle was the most readily predicted by the model. This was low overall, with a mean of 2.26 , but it was significantly higher for students who described themselves as being extrovert and taking a less conscientious approach to life (Metcalf, 2005; McManus and Furnham, 2006; Harrison and Chudry, 2011). Women were also significantly less likely to see debt as being for maintaining a preferred lifestyle, echoing previous literature around debt aversion for this group (Croson and Gneezy, 2009; Kettley, Whitehead and Raffan, 2008).

Interestingly, the lifestyle dimension was the only one predicted by financial literacy. This relationship was statistically significant, but the effect size was small, with someone achieving five correct answers scoring an average of .35 points lower on the lifestyle scale compared to those scoring none. Financial literacy is hypothesised to reduce impulsive credit use (e.g. de Bassa Schreseberg, 2013) and this finding would tend to support this, with more knowledge about financial matters being linked to a lower disposition towards credit use for social and luxury purposes. As found in most earlier studies (e.g. Lusardi and Mitchell, 2008; 2014), women had significantly lower financial literacy, while NZ students scored more highly than English students, all else being equal; business students and mature students also got more questions correct.

When the study was conceived, it was hypothesised that financial literacy would play a much greater part in the explanatory model. However, it was found to have no significant relationship with three of the debt attitude dimensions and only a modest one with the fourth. In particular, it is counterintuitive for financial literacy to be unrelated to a student's awareness of the student finance system, while knowing more about the world of finance did nothing to mitigate (or exacerbate) 
anxiety about indebtedness. This casts some doubt on the efficacy of school-based financial literacy programmes in assisting young people to make informed decisions about higher education.

There was clear variability in the level of anxiety about indebtedness. Business students had lower levels, but this was not mediated through financial literacy, which suggests that it is not businessspecific knowledge that lowers anxiety; rather, it may reflect confidence about higher long-term earnings (Walker and Zhu, 2011). Anxiety about indebtedness is predicted by a disposition towards generalised anxiety, as reflected in the neuroticism scale. In keeping with previous studies (Schmitt et al., 2008), this is higher for women and thus this anxiety transfers from being generalised to being specific; the students who were more worried about their debt were those most prone to worrying in their life. This gender difference articulates well with Kettley et al.'s (2008) work on differing financial strategies for female students, with the latter appearing to be more concerned than men with comparable levels of indebtedness. More generally, the results of this study support other studies that find students with similar financial circumstances having different attitudinal responses (e.g. Christie et al., 2004; Harding, 2011).

NZ students were found to have somewhat higher levels of anxiety around indebtedness relative to English students; this is another unexpected finding from this study. One might have hypothesised that NZ students would be less prone to anxiety about their debt given that it is smaller and declines in value over time. However, there is a higher propensity to repay loans early in NZ (Ministry of Education, 2015a), which may reflect higher levels of anxiety among students (and, potentially, their families). Alternatively, the English students may be collectively reassured by the preferential threshold and repayment rate, making their debt seem less onerous despite its larger overall size.

As noted above, belief in the value of student debt as a personal educational investment was generally high within the sample, with a mean of 4.10. The strongest direct predictor for this belief 
was degree subject, with business students having more confidence that the debt accumulated at university would lead to better chances of procuring highly-paid work; this belief may be wellfounded (Walker and Zhu, 2011). Men and NZ students also shared a higher score on this scale, although in both cases this was negatively mediated through conscientiousness, such that the overall effect size was relatively modest.

Perhaps the most important finding, however, is that one of the key variables hypothesised in the literature to impact on debt attitudes was found not to do so. As noted earlier, the study collected data about parental education levels with the intention of using this as a proxy for socio-economic status. Various constructions (e.g. higher education qualifications or progress beyond compulsory age) were explored and none was found to be statistically meaningful. Furthermore, NZ data were available in relation to the socio-economic status of the areas from which schools attended by the participants drew their students and this variable was also found not be a useful predictor. In other words, no evidence was found to suggest that social class was a predictor for any of the four dimensions of debt attitude explored in this study. This is counter to some previous literature (especially Callender and Jackson, 2005) and is, of course, not to deny that individuals from disadvantaged backgrounds do suffer anxiety about their debt, but simply that this is no more prevalent than among more advantaged students, on average. It is important to remember that this study purposefully excluded prospective students, so it is impossible to draw conclusions about any deterrent effect of debt, although the results are consistent with recent patterns in the demand for higher education, which has continued to rise from disadvantaged students, even across increases in average student debt levels (McLaughlin, 2003; HEFCE, 2013; ICF, 2014).

Finally, it is important to note that there were two-way relationships between the debt attitude dimensions. In particular, all else being equal, higher anxiety was associated with the use of debt for lifestyle, but lower scores for awareness and educational investment. This suggests that anxiety 
about debt may be driven, in part, by its unwise use, although it may also be that credit is used to alleviate anxiety. In addition, the negative relationship between anxiety and awareness is interesting, although it is unclear the extent whether anxiety is caused by a lack of information about debt or whether more anxious students choose 'blissful ignorance' about their indebtedness. There was a reinforcing relationship between awareness and the belief in debt as an educational investment, such that those students with the most knowledge about their student loan were also more likely to see it as offering long-term benefits. Finally, the negative relationship between anxiety and educational investment suggests that confidence about the long-term benefit of higher education can ameliorate short-term strains (Purcell and Elias, 2010; Bachan, 2013; Esson and Ertl, in press).

\section{Limitations}

This study has a number of limitations. Firstly, there are likely to be other, currently unknown, factors that influence debt attitudes. Possible additions for future studies include measures of risk tolerance, long-term planning, materialism and impulsiveness. This study purposefully did not ask students about their level of debt, partly as students' recollections may be unreliable and partly as it was expected that accrued debt would be broadly similar soon after registration; however, this could be explored in the future.

Secondly, data collection was confined to two universities and two academic disciplines. While broadly typical of the national context in terms of status and demographic mix, it is possible that the findings attributed to nations are, in fact, features of the specific universities. There is no obvious reason why this should be the case, but future research could collect data from a wider pool of universities to control for this. Similarly, it is likely that different patterns of debt attitude would be 
found in other disciplines, but it was felt important to provide a degree of control in this study to account for different student/subject mixes across universities. Naturally the claims in the paper can only be made with confidence about students in these two disciplines.

Thirdly, the data collected on ethnicity, agreeableness and openness-to-experience were discarded. Exploratory analysis suggested that there were some relationships between ethnicity and debt attitudes, but small numbers and diversity meant that it was not possible to analyse this with confidence. The two personality variables were omitted as the measure was not felt to be sufficiently internally reliable. This casts doubt on the use of two-item inventories and future studies are likely to be enhanced by more items to provide stronger reliability.

Finally, two of the variables within the study did not behave as hypothesised: parental education (as a proxy for socio-economic status) and financial literacy. It may, of course, be that the initial conceptual model was simply flawed, but it could also be that the reliability or internal validity of these measures were compromised. Alternative approaches to these variables were explored (e.g. looking at the financial literacy questions individually), but without changing the overall results; there is, therefore, scope to experiment with different measures in the future.

\section{Conclusion}

This study sought to better understand undergraduate students' debt attitudes in the period immediately after starting higher education, using data from two countries with contrasting student loan regimes in terms of the amounts offered, interest accrued and repayment schedules. 
Three of the findings are likely to be of interest to policymakers. Firstly, the extent to which a student saw their debt as an educational investment was mediated through their subject choice, with business students having higher confidence in a return than social science students; this likely reflects graduate salary expectations. Secondly, debt anxiety, which previous literature suggests is likely to compromise academic success, was higher for women, social science students and NZ students. These two attitudes were negatively related, such that anxiety was lower when confidence in educational investment was high. Thirdly, the data suggest that policy interventions to increase students' awareness of workings of the student loan system may increase confidence and lower anxiety, although causation is difficult to disentangle.

In policy terms, student debt has two potential pitfalls: deterring applications, and undermining academic achievement, directly through anxiety and indirectly through debt avoidance strategies (e.g. part-time work). The former was purposefully not explored in this study, although this study does demonstrate that students have differing level of belief in a financial return-on-investment, which may impact on demand. This study does shed new light on the latter, however, by revealing specific factors which predict anxiety, as well as demonstrating that improved information about student debt and an increased belief in long-term value of higher education may mitigate this anxiety.

In addition, the contrast between England and NZ in this study was particularly interesting. The NZ government provides for lower student loans in comparison to England, yet its students appear to be more anxious about their debt. The reasons for this are beyond this study, but it could relate to the cultural meanings attached to debt or that the less onerous repayment terms in England also help to mitigate anxiety. 
In conclusion, this study finds students' debt attitudes to be complex and mediated through a range of social and personal variables - i.e. responses to similar levels of indebtedness differ between individuals. In particular, this study finds no systematic socio-economic basis for students' debt attitudes, although there are acknowledged limitations in the variable used. Instead, this study supports an attitudinal model which sees short-term anxiety and long-term confidence in a state of flux, and where those that are anxious about debt are influenced by dispositions that are not necessarily related to the scale of debt accrued. 


\section{Endnotes}

[1] The figures provided in this section are an approximation of the prevailing student loan systems, as both have complexities for which there is insufficient space to detail here. For example, in England, students loan limits are lower for those living in the family home. However, the explanations given provide a reasonable overview of the systems as experienced by the participants in the study. Approximately, $£ 1=\mathrm{NZ} \$ 2$.

[2] For visual simplicity, the degree subject variable is rendered here as a covariate with the other social factors, whereas it is, in reality, partially predicted by them. This compromise makes no difference to the model or the results.

[3] Separate analyses were also undertaken for the England and NZ subsamples, but the resulting models were not found to be substantially different. There was some indication that age and gender were slightly more important predictors in England, while subject choice was slightly more important in NZ. However, the subsample sizes were relatively small and these observations are therefore only tentative. 


\section{References}

Bachan, R. (2013) Students' Expectations of Debt in UK Higher Education, Studies in Higher Education, 39 (5), pp. 848-873.

Blunch, N. (2013) Introduction to Structural Equation Modelling using IBM SPSS Statistics and AMOS. London: Sage.

Callender, C. and Jackson, J. (2005) Does the Fear of Debt Deter Students from Higher Education? Journal of Social Policy, 34 (4), pp. 509-540.

Christie, H., Munro, M. and Fisher, T. (2004) Leaving University Early: Exploring the Differences between Continuing and Non-continuing Students, Studies in Higher Education, 29 (5), pp. 617-636.

Chudry, F., Foxall, G. and Pallister, J. (2011) Exploring Attitudes and Predicting Intentions: Profiling Student Debtors Using an Extended Theory of Planned Behaviour, Journal of Applied Social Psychology, 41 (1), pp. 119-149.

Cooke, R., Barkham, M., Audin, K., Bradley, M. and Davy, J. (2004) Student Debt and its Relation to Student Mental Health, Journal of Further and Higher Education, 28 (1), pp. 53-66.

Croson, R. and Gneezy, U. (2009) Gender Differences in Preferences, Journal of Economic Literature, 47 (2), pp. 448-474.

Davies, E. and Lea, S. (1995) Student Attitudes to Student Debt, Journal of Economic Psychology, $16(4)$, pp. 663-679.

Davies, P., Slack, K., Hughes, A., Mangan, J. and Vigurs, K. (2008) Knowing Where to Study: Fees, Bursaries and Fair Access. Stoke-on-Trent: Institute for Educational Policy Research and Institute for Access Studies.

Davies, P., Mangan, J., Hughes, A. and Slack, K. (2013) Labour Market Motivation and Undergraduates' Choice of Degree Subject, British Educational Research Journal, 39 (2), pp. 361-382. 
de Bassa Scheresberg, C. (2013) Financial Literacy and Financial Behavior among Young Adults:

Evidence and Implications, Numeracy, 6 (2), DOI:10.5038/1936-4660.6.2.5.

Department of Business, Innovation and Skills (2013) Student Income and Expenditure Survey 2011/12: English-Domiciled Students. London: BIS.

Department of Innovation, Universities and Skills (2009) Student income and expenditure survey 2007/08: English-domiciled students. London: DIUS.

Dwyer, R., Hodson, R. and McCloud, L. (2013) Gender, Debt, and Dropping out of College, Gender \& Society, 27 (1), pp. 30-55.

Eckel, C., Johnson, C., Montmarquette, C. and Rojas, C. (2007) Debt Aversion and the Demand for Loans for Postsecondary Education, Public Finance Review, 35 (2), pp. 233-262.

Esson, J. and Ertl, H. (in press) No Point Worrying? Potential Undergraduates, Study-Related Debt, and the Financial Allure of Higher Education, Studies in Higher Education, DOI:10.1080/03075079.2014.968542.

Gorard, S., Adnett, N., May, H., Slack, K., Smith, E. and Thomas, L. (2006) Overcoming the Barriers to Higher Education. Stoke-on-Trent: Trentham.

Grove, J. (2014) Mature Student Numbers 'Hit Record Level', Times Higher Education, $22^{\text {nd }}$ August.

Hall, R. (2010) The Work-Study Relationship: Experiences of Full-Time University Students Undertaking Part-Time Employment, Journal of Education and Work, 23 (5), pp. 439-449.

Harding, J. (2011) Financial Circumstances, Financial Difficulties and Academic Achievement among First-Year Undergraduates, Journal of Further and Higher Education, 35 (4), pp. 483499.

Harrison, N., Agnew, S. and Serido, J. (2015) Attitudes to Debt Among Indebted Undergraduates: A Cross-National Exploratory Factor Analysis, Journal of Economic Psychology, 46, pp. 6273. 
Harrison, N. and Chudry, F. (2011) Overactive, Overwrought or Overdrawn? The Role of

Personality in Undergraduate Financial Knowledge, Decision-Making and Debt, Journal of Further and Higher Education, 35 (2), pp. 149-182.

Harrison, N., Chudry, F., Waller, R. and Hatt, S. (2015) Towards a Typology of Debt Attitudes among Contemporary Young UK Undergraduates, Journal of Further and Higher Education, 39 (1), pp. 85-107.

Haultain, S., Kemp, S. and Chernishenko, O. (2010) The Structure of Attitudes to Student Debt, Journal of Economic Psychology, 31, pp. 322-330.

Higher Education Funding Council for England (2013) Trends in Young Participation in Higher Education (Report 2013/28). Bristol: HEFCE.

Higher Education Statistics Agency (2015) Destinations of Leavers. Available at https://www.hesa.ac.uk/stats-dlhe.

Hilgert, M., Hogarth, J. and Beverly, S. (2003) Household Financial Management: The Connection between Knowledge and Behavior, Federal Reserve Bulletin, 89 (7), pp. 309-22.

Independent Commission on Fees (2014) Analysis of Trends in Higher Education Applications, Admissions, and Enrolments. London: ICF.

Jessop, D., Herberts, C. and Soloman, L. (2005) The Impact of Financial Circumstances on Student Health, British Journal of Health Psychology, 10 (3), pp. 421-439.

Kamleitner, B., Hoelzl, E. and Kirchler, E. (2012) Credit Use: Psychological Perspectives on a Multifaceted Phenomenon, International Journal of Psychology, 47 (1), pp. 1-27.

Kettley, N., Whitehead, J. and Raffan, J. (2008) Worried Women, Complacent Men? Gendered Responses to Differential Student Funding in Higher Education, Oxford Review of Education, 34 (1), pp. 111-129.

Leach, L. (2013) Participation and Equity in Higher Education: Are we Going Back to the Future, Oxford Review of Education, 39 (2), pp. 267-286. 
Lusardi, A. and Mitchell, O. (2007) Financial Literacy and Retirement Preparedness: Evidence and Implications for Financial Education, Business Economics, 42 (1), pp. 35-44.

Lusardi, A. and Mitchell, O. (2008) Planning and Financial Literacy: How do Women Fare? American Economic Review, 98 (2), pp. 413-417.

Lusardi, A. and O. Mitchell. (2014) The Economic Importance of Financial Literacy: Theory and Evidence, Journal of Economic Literature, 52 (1), pp. 5-44.

Mandell, L. (2008) The Financial Literacy of Young American Adults. Available at http://www.jumpstart.org/assets/files/2008SurveyBook.pdf.

Maringe, F., Foskett, N. and Roberts, D. (2009) 'I Can Survive on Jam Sandwiches for the Next Three Years': The Impact of the New Fees Regime on Students' Attitudes to HE and Debt, International Journal of Educational Management, 23 (2), pp. 145-160.

Marriott, P. (2007) An Analysis of First Experience Students' Financial Awareness and Attitude to Debt in a Post-1992 UK University, Higher Education Quarterly, 61 (4), pp. 498-519.

McLaughlin, M. (2003) Tertiary Education Policy in New Zealand. Available at www.fulbright.org.nz/voices/axford/docs/mcLaughlin.pdf.

McManus, I. and Furnham, A. (2006) Aesthetic Activities and Aesthetic Attitudes: Influences of Education, Background and Personality on Interest and Involvement in the Arts, British Journal of Psychology, 97 (4), pp. 555-587.

Metcalf, H. (2005) Paying for University: The Impact of Increasing Costs on Student Employment, Debt and Satisfaction, National Institute Economic Review, 19 (1), pp. 106-117.

Mottola, G. (2013) In Our Best Interest: Women, Financial Literacy, and Credit Card Behavior, Numeracy, 6 (2), DOI:10.5038/1936-4660.6.2.4.

Ministry of Education (2005) Student Loans Among Māori Students. Wellington: New Zealand Ministry of Education.

Ministry of Education (2015a) Student Loan Scheme Annual Report 2014/15. Wellington: New Zealand Ministry of Education. 
Ministry of Education (2015b) Life After Study. Available at https://www.educationcounts.govt.nz/ statistics/tertiary_education/life_after_study.

National Audit Office (2007) Staying the Course: The Retention of Students in Higher Education. London: The Stationary Office.

Nicholson, N., Soane, E., Fenton-O’Creevy, M. and Willman, P. (2005) Personality and DomainSpecific Risk Taking, Journal of Risk Research, 8 (2), pp. 157-176.

Norvilitis, J., Merwin, M., Osberg, T., Roehling, P., Young, P. and Kamas, M. (2006) Personality Factors, Money Attitudes, Financial Knowledge and Credit-Card Debt in College Students, Journal of Applied Social Psychology, 36 (6), pp. 1395-1413.

Office for Fair Access (2015) What do we Know about the Impact of Financial Support on Access and Student Success? Bristol: OFFA.

Organisation for Economic Cooperation and Development (2014) PISA 2012 Results: Students and Money: Financial Literacy Skills for the 21st Century. Paris: OECD Publishing.

Patiniotis, J. and Holdsworth, C. (2005) 'Seize that chance!' Leaving Home and Transitions to Higher Education, Journal of Youth Studies, 8 (1), pp. 81-95.

Peltier, J., Pomirleanu, N., Endres, M. and Markos, E. (2013) Psycho-Social Factors Impacting Credit Acquisition and Use by College Students, Journal of Financial Services Marketing, 18, pp. 271-284.

Purcell, K., and Elias, P. (2010) The Impact of Paid and Unpaid Work and of Student Debt on Experience of Higher Education. Coventry: Warwick Institute for Employment Research. Purcell, K., Elias, P., Ellison, R., Atfield, G., Adam, D. and Livanos, I. (2008) Applying for Higher Education: The Diversity of Career Choices, Plans and Expectations. Coventry: Warwick Institute for Employment Research.

Quinn, J., Thomas, L., Slack, K., Casey, L., Thexton, W. and Noble, J. (2005) From Life Crisis to Lifelong Learning: Rethinking Working-Class 'Drop Out' from Higher Education. York: Joseph Rowntree Foundation. 
Rammstedt, B. and John, O. (2007) Measuring Personality in One Minute or Less: A 10-item Short Version of the Big Five Inventory in English and German, Journal of Research in Personality, 41 (1), pp. 203-212.

Richardson, J., Kemp, S., Malinen, S. and Haultain, S. (2013) The Academic Achievement of Students in a New Zealand University: Does it Pay to Work? Journal of Further and Higher Education, 37 (6), pp. 864-882.

Schmitt, D., Realo, A., Voracek M. and Allik, J. (2008) Why Can't a Man be More Like a Woman? Sex Differences in Big Five Personality Traits across 55 Cultures, Journal of Personality and Social Psychology, 94 (1), pp. 168-182.

Shim, S., Xiao, J., Barber, B. and Lyons, A. (2009) Pathways to Life Success: A Conceptual Model of Financial Well-Being for Young Adults, Journal of Applied Developmental Psychology, 30 (6), pp. 708-723.

Simon, H. (2000) Bounded Rationality in Social Science: Today and Tomorrow, Mind and Society, $1(1)$, pp. 25-39.

Union of Students' Associations (2014) Student Loan Debt Continues to Climb - And Students' Fear For The Future Mounts With It. Available at http://www.students.org.nz/student_loan_debt_continues_to_climb_and_students_fear_for_the _future_mounts_with_it

Usher, A. (2005) Global Debt Patterns: An International Comparison of Student Loan Burdens and Repayment Conditions. Toronto: Educational Policy Institute.

Walker, I. and Zhu, Y. (2011) Differences by Degree: Evidence of the Net Financial Rates of Return to Undergraduate Study for England and Wales, Economics of Education Review, 30 (6), pp. 1177-1186.

Watson, S., Barber, B. and Dziurawiec, S. (2014) The Role of Economizing and Financial Strain in Australian University Students' Psychological Well-Being, Journal of Family and Economic Issues, DOI:10.1007/s10834-014-9404-5. 
Wilkins, S., Shams, F. and Huisman, J. (2013) The Decision-Making and Changing Behavioural Dynamics of Potential Higher Education Students: The Impacts of Increasing Tuition Fees in England, Educational Studies, 39 (2), pp. 125-141. 
Table 1: Sample composition

\begin{tabular}{|l|c|c|c|}
\hline & England & New Zealand & ALL \\
\hline Female & $133(66.8 \%)$ & $148(61.7 \%)$ & $281(64.0 \%)$ \\
\hline Male & $66(33.2 \%)$ & $92(38.3 \%)$ & $158(36.0 \%)$ \\
\hline Young (18-21) & $180(90.5 \%)$ & $207(86.2 \%)$ & $387(88.2 \%)$ \\
\hline Mature (22 and over) & $19(9.5 \%)$ & $33(13.8 \%)$ & $52(11.8 \%)$ \\
\hline Business & $124(62.3 \%)$ & $126(52.5 \%)$ & $250(56.9 \%)$ \\
\hline Social science & $75(37.7 \%)$ & $114(47.5 \%)$ & $189(43.1 \%)$ \\
\hline Majority ethnicity & $178(89.4 \%)$ & $208(87.8 \%)$ & $384(87.8 \%)$ \\
\hline Minority ethnicity & $21(10.6 \%)$ & $32(13.2 \%)$ & $53(12.1 \%)$ \\
\hline Mother has degree & $43(21.6 \%)$ & $91(37.9 \%)$ & $134(30.5 \%)$ \\
\hline Mother without degree & $156(78.4 \%)$ & $149(62.1 \%)$ & $305(69.5 \%)$ \\
\hline Father has degree & $54(27.1 \%)$ & $94(39.2 \%)$ & $148(33.7 \%)$ \\
\hline Father without degree & $145(72.9 \%)$ & $146(60.8 \%)$ & $291(66.3 \%)$ \\
\hline
\end{tabular}

Table 2: Means (standard deviations) of the continuous variables

\begin{tabular}{|l|c|c|c|}
\hline & England & New Zealand & ALL \\
\hline EXT & $3.45(.786)$ & $3.15(.876)$ & $3.28(.848)$ \\
\hline NEU & $3.06(.934)$ & $3.09(.856)$ & $3.08(.891)$ \\
\hline CON & $3.84(.776)$ & $3.60(.756)$ & $3.71(.774)$ \\
\hline ANX & $2.25(.894)$ & $2.45(.872)$ & $2.36(.866)$ \\
\hline INVEST & $4.07(.551)$ & $4.13(.534)$ & $4.10(.542)$ \\
\hline LIFE & $2.29(.874)$ & $2.24(.879)$ & $2.26(.876)$ \\
\hline AWARE & $3.81(.874)$ & $3.80(.832)$ & $3.80(.832)$ \\
\hline FLSCORE & $2.83(1.164)$ & $3.63(1.027)$ & $3.27(1.160)$ \\
\hline
\end{tabular}

Means expressed on 1 to 5 rising scale, with the exception of FLSCORE which ranges from 0 to 5 . 
Table 3: Regression weights for path model

\begin{tabular}{|lllcccc|}
\hline & & & $\begin{array}{c}\text { Coefficient } \\
\text { estimate }\end{array}$ & S.E. & $\begin{array}{c}\text { Critical } \\
\text { ratio }\end{array}$ & p-value \\
\hline Female & $--->$ & CON & .185 & .075 & 2.471 & .013 \\
Female & $--->$ & NEU & .496 & .081 & 6.129 & $<.001$ \\
NZ & $--->$ & FLSCORE & .785 & .101 & 7.809 & $<.001$ \\
Female & $--->$ & FLSCORE & -.418 & .114 & -3.678 & $<.001$ \\
Business & $--->$ & FLSCORE & .272 & .111 & 2.440 & .015 \\
Mature & $--->$ & FLSCORE & .480 & .155 & 3.085 & .002 \\
NZ & $--->$ & EXT & -.277 & .075 & -3.671 & $<.001$ \\
NZ & $--->$ & CON & -.219 & .071 & -3.082 & .002 \\
NEU & $--->$ & ANX & .179 & .043 & 4.189 & $<.001$ \\
Female & $--->$ & INVEST & -.132 & .054 & -2.469 & .014 \\
Business & $--->$ & ANX & -.303 & .081 & -3.751 & $<.001$ \\
Business & $--->$ & INVEST & .198 & .054 & 3.646 & $<.001$ \\
CON & $--->$ & AWARE & .173 & .050 & 3.486 & $<.001$ \\
NZ & $--->$ & ANX & .156 & .079 & 1.970 & .049 \\
CON & $--->$ & INVEST & .093 & .031 & 2.970 & .003 \\
NZ & $--->$ & INVEST & .098 & .050 & 1.977 & .048 \\
EXT & $--->$ & LIFE & .266 & .045 & 5.921 & $<.001$ \\
CON & $--->$ & LIFE & -.284 & .050 & -5.728 & $<.001$ \\
Mature & $--->$ & LIFE & -.320 & .117 & -2.729 & .006 \\
Female & $--->$ & LIFE & -.243 & .081 & -2.999 & .003 \\
FLSCORE & $--->$ & LIFE & -.074 & .034 & -2.175 & .030 \\
EXT & $--->$ & AWARE & -.133 & .046 & -2.870 & .004 \\
NEU & $--->$ & AWARE & -.123 & .045 & -2.748 & .006 \\
Business & $--->>$ & AWARE & .229 & .078 & 2.951 & .003 \\
Mature & $--->>$ & AWARE & .241 & .116 & 2.085 & .037 \\
\hline
\end{tabular}

Table 4: Covariances within path model

\begin{tabular}{|c|c|c|c|c|c|c|}
\hline & & & $\begin{array}{l}\text { Coefficient } \\
\text { estimate }\end{array}$ & $\begin{array}{l}\text { Standard } \\
\text { error }\end{array}$ & $\begin{array}{c}\text { Critical } \\
\text { ratio }\end{array}$ & p-value \\
\hline Female & $<-->$ & Business & -.098 & .012 & -8.036 & $<.001$ \\
\hline $\mathbf{N Z}$ & $<-->$ & Business & -.028 & .011 & -2.556 & .011 \\
\hline Business & $<-->$ & Mature & -.022 & .007 & -3.158 & .002 \\
\hline $\mathrm{CON}$ & $<-->$ & EXT & .065 & .030 & 2.144 & .032 \\
\hline NEU & $<-->$ & EXT & -.243 & .036 & -6.690 & $<.001$ \\
\hline $\mathrm{CON}$ & $<-->$ & NEU & -.146 & .032 & -4.548 & $<.001$ \\
\hline ANX & $<-->$ & INVEST & -.136 & .022 & -6.315 & $<.001$ \\
\hline ANX & $<-->$ & AWARE & -.113 & .032 & -3.521 & $<.001$ \\
\hline ANX & $<-->$ & LIFE & .135 & .031 & 4.289 & $<.001$ \\
\hline INVEST & $<-->$ & AWARE & .088 & .020 & 4.349 & $<.001$ \\
\hline
\end{tabular}




\section{Appendix A}

\begin{tabular}{|l|l|}
\hline Scale & Items \\
$\begin{array}{l}\text { ANX } \alpha=.817) \\
\text { I sometimes can't sleep because I worry about how much debt I am in } \\
\text { I worry about debt to the point where it affects my grades } \\
\text { I feel isolated by my student debt } \\
\text { I worry that the repayments on my debt will become unaffordable }\end{array}$ \\
\hline $\begin{array}{l}\text { INVEST } \\
(\alpha=.643)\end{array}$ & $\begin{array}{l}\text { Even though I am incurring debt now, it will be worth it in the future } \\
\text { I have a greater chance of getting a job if I have a degree } \\
\text { I expect to earn more in the future because I went to university } \\
\text { Educational loan debt is a good investment for the future }\end{array}$ \\
\hline $\begin{array}{l}\text { LIFE } \\
(\alpha=.760)\end{array}$ & $\begin{array}{l}\text { I use debt to pay for a good social life } \\
\text { I use debt to pay for luxuries } \\
\text { I use debt so I don't miss out on 'normal' student experiences }\end{array}$ \\
\hline $\begin{array}{l}\text { AWARE } \\
(\alpha=.721)\end{array}$ & $\begin{array}{l}\text { I feel I have a good understanding of how student loans work } \\
\text { I know about the repayment terms for my student loan } \\
\text { I have a good idea about how much student loan debt I am incurring }\end{array}$ \\
\hline
\end{tabular}


Figure 1: conceptual model

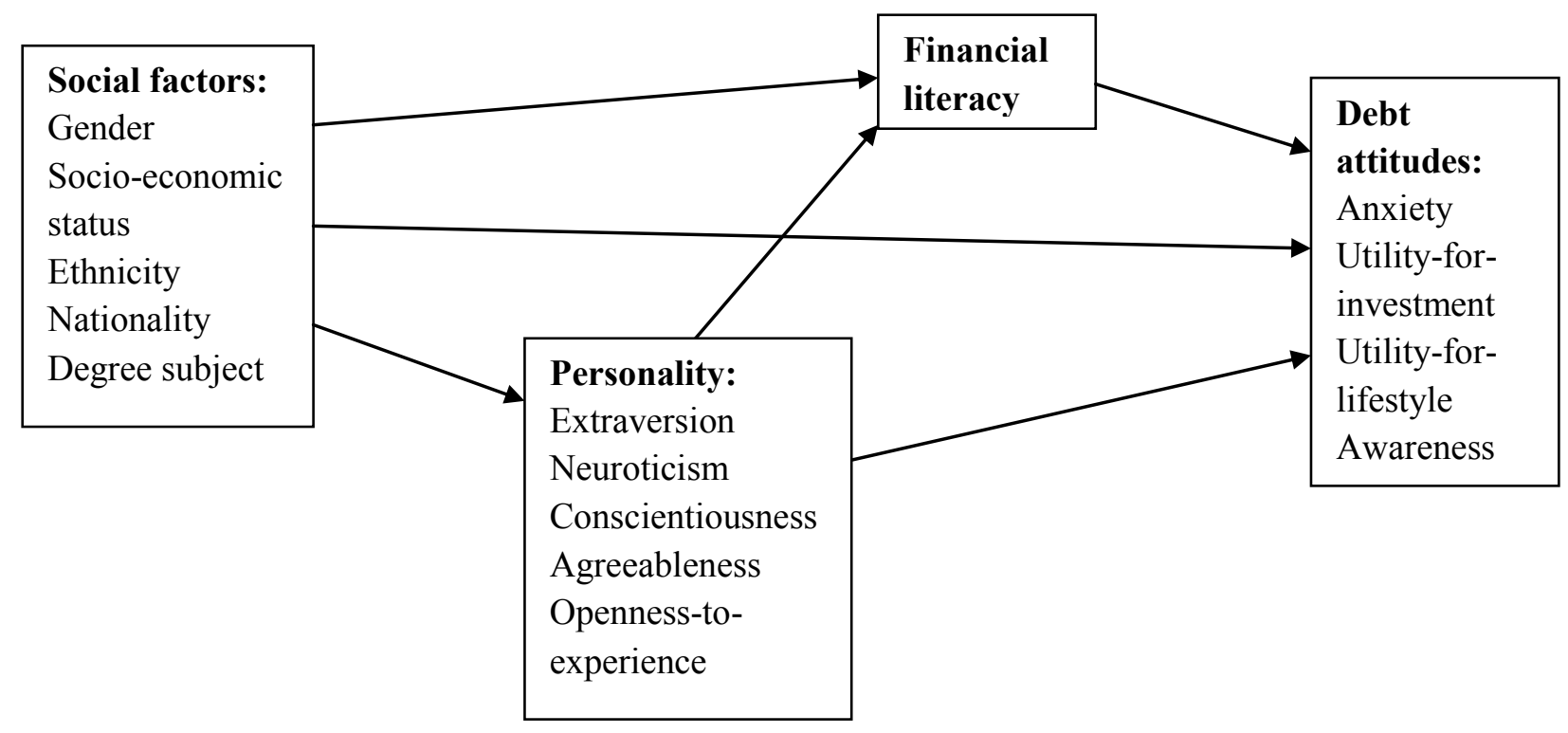


Figure 2: path diagram with regression weights and covariances

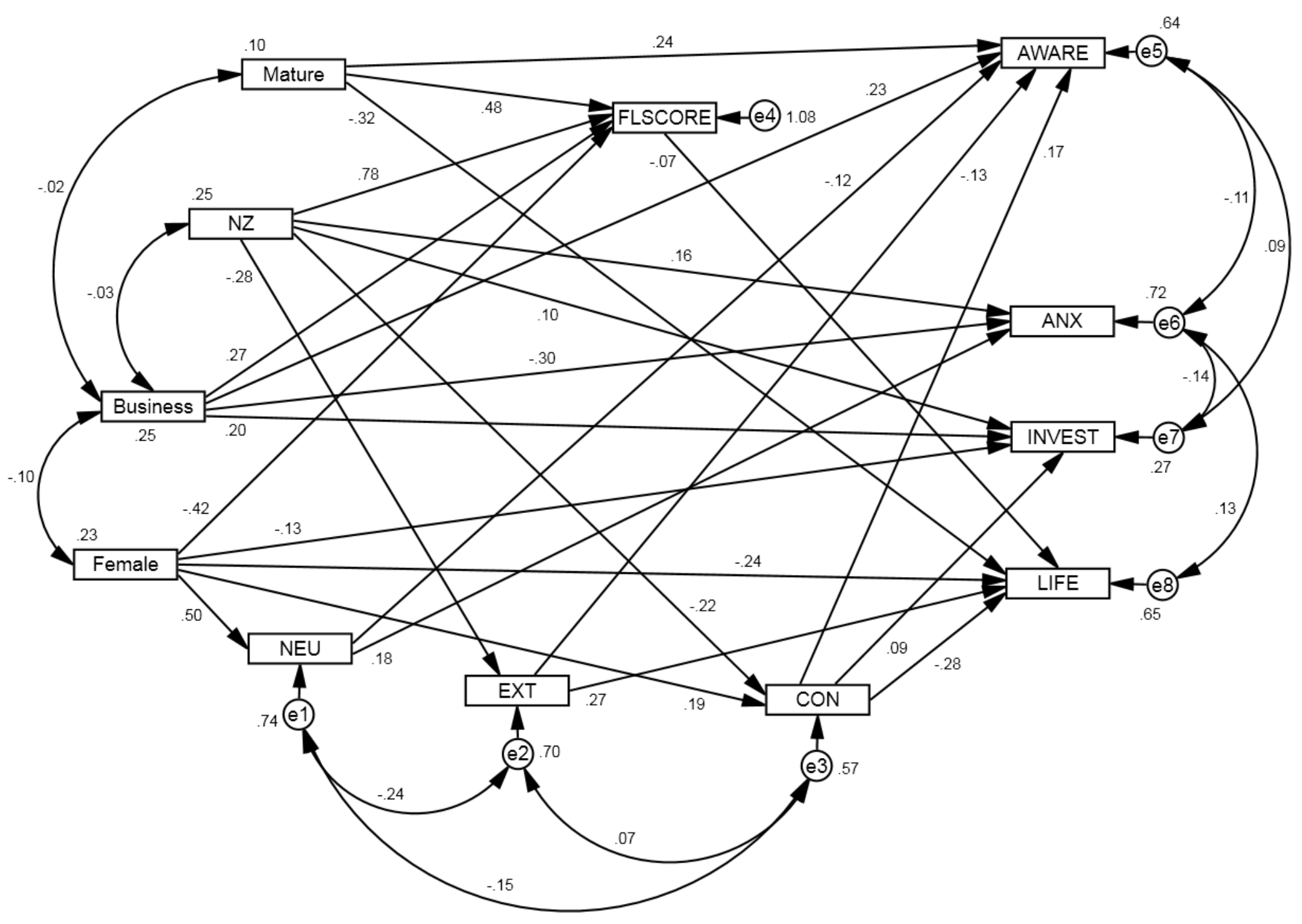

(NB: The variables labelled Mature, NZ, Business and Female are dummy variables, with a reference category of Young, England, Social Science and Male respectively) 